constructed a most ingenious model from Meccano to illustrate the working of this complicated instrument. Without something of the sort, it is very difficult to understand how it functions.

Brigadier MacLeod pleads for the co-ordination of African surveys. He points out that some kind of arrangement should be come to among the various nations possessing African territory with the view of adopting uniformity of scales and projection of maps, before it is too late. So far, this has been achieved only in the case of the International "Carte du Mond" on the $1 / 1,000,000$ scale. He also urges the adoption of the metric unit. The progress of aviation has made this necessary since the airman passes so quickly from one territory to another. Unless something is done, Africa of the future will be saddled with a multiplicity of scales, styles and projections. As no other nation is likely to adopt the British units of measurement, unless we change to the metric system, yet another complication will be added to the map difficulties of the airman.

Before the conference terminated, resolutions were passed recommending that a central pool of survey instruments should be formed from which Dominions and Colonies could borrow on certain terms; that the Empire Survey Review should be continued notwithstanding some loss, as a means of keeping up the standards of surveying technique; a resolution emphasizing the necessity for basing all categories of survey on a proper geodetic foundation; a resolu. tion recording the opinion of the conference as to the value of its proceedings for the discussion and interchange of views on the improvement of survey technique. The conference also decided that it is desirable to hold triennial conferences lasting for two weeks.

H. L. C.

\title{
Electrical Interference with Broadcasting
}

$\mathrm{T}$ HREE years ago the Institution of Electrical Engineers appointed a special committee to consider the trouble caused by the interference of various kinds of electrical devices with radio reception. This nuisance has been gradually getting worse owing to the growing sensitivity of modern receivers. The report has now been published (Inst. Elec. Eng., Savoy Place, W.C.2. 6d. post paid) and was commented upon in Nature of August 1. The committee was fully representative of all sections of the industry on both the radio and engineering sides.

A method of measurement of interference has been agreed upon, and instruments have been developed capable of indicating with sufficient accuracy the amount of interference caused by much of the electrical apparatus which causes trouble. The technical position has been cleared up, and it is considered that no undue extra expense will be involved in the design and construction of apparatus that will bring the interference caused within an acceptable standard. The apparatus which is likely to cause the most interference is classified as follows : (1) lifts in buildings ; (2) trolley-buses and trams; (3) household electrical appliances; (4) small electric motors ; (5) 'neon' display signs ; (6) certain rectifiers for power plant and (7) electro-medical apparatus. In an appendix to the report, a brief account is given of the researches undertaken in connexion with these seven groups.

In addition, although there is at present little interference with ordinary broadcast reception due to the ignition systems on motor-vehicles, it is probable that, unless corrected, it will interfere with the television reception of the future. There are other causes of radio interference such as electric signalling gear on railways, but at present they produce only minor effects. Real progress has been made in finding the most effective methods of correction in each of the seven groups given above. As a result of Post Office activity, a considerable amount of radio interference correction has been taking place during the last few years.

The first case where radio interference correction was in effect made compulsory was that of traffic signals. The Ministry of Transport now requires all traffic signals to be fitted with components which effectively prevent interference. This was achieved without much difficulty. The second case was that of trolley-buses, where much practical progress has been made. It is now clear that the various technical aspects of the problem are approaching solution, and it is necessary to consider whether compulsory powers should be conferred on some authority so that radio interference may be suppressed in those cases where it can only be done with the help of such an authority. The manufacturers of appliances and plant definitely support the view that there should be some recognized 'mark' which could be affixed to all portable apparatus as a guarantee that the apparatus complies with noninterference requirements. They consider that the sale of appliances which do not meet those requirements should be prohibited. It is essential that imported articles should be subject to the same regulations as home-produced articles and should bear the 'mark'. It is only through legislation that this question can be dealt with successfully. As a rule, it is not the man who buys and uses the apparatus, but his neighbour, who suffers from the resulting interference.

In view of the fact that it is generally cheaper to incorporate suppression devices in the original design of the equipment than to fit them after installation, it is recommended that compulsory powers should be conferred on some authority. It is anticipated that there will be only a small number of owners of interfering equipment who will refuse to apply remedial measures. It is recommended that the Electricity Commissioners should be the authority to issue regulations regarding both new and existing equipments and that the Post Office be charged with enforcing them. British Standards Specifications have already been issued giving the standard ratings for condensers, 'resistors', inductors and similar apparatus for incorporation in suppression devices. The specification for a standard interferenee-measuring instrument will cover the characteristics and performance requirements recommended by the Special International Committee on Radio Interference. It will include a detailed design for a portable instrument which will enable manufacturers to 
ascertain what values of components should be used to reduce interference within the prescribed limits.

In a statement made by $\mathrm{Mr}$. C. C. Paterson, the chairman of the Committee, concerning the report, he points out that should the regulations be put into foree, the normal procedure would be very much as at present. There would not be an army of inspectors searching out for trouble. Action would only be taken by the Post Office on receipt of a complaint of interference, and these complaints would become fewer in number as new apparatus bearing the 'mark' came into use.

\section{Industrial Development in South Africa}

$\mathrm{T}$ HE Department of Commerce and Industry of the Government of the Union of South Africa has published a review of the material, scientific and educational progress made in connexion with the development of industry during the twenty-five years up to 1935*. Primarily, its purpose is to give an accurate picture of the conditions and prospects in what are described as the secondary industries, for agriculture and mining are otherwise dealt with and are only referred to in so far as they have a bearing on the other and less firmly established industries. The information it contains as to the conditions, facilities, costs, etc., in various districts and the progress of the numerous industries which have been established will also be found to supply a valuable scientific interpretation of the facts for the use of those who are or may become interested in the industrial future of the country.

In round numbers, the following figures give a picture of the expansion that has taken place in the twenty-five year period-employees have increased from 66,000 to 195,000 , horse-power from 140,000 to $1,400,000$, and total wages from 4 to 27 million pounds. The classes of industries dealt with and analysed statistically include fuel industries, iron and steel production, heavy chemicals and food production (sugar, wines and fisheries), together with other important developments which are taking place in connexion with the introduction of such manufactures as cement, pottery, clothing and textiles.

In these changes, the importance of research appears to be fully realized, and it is being fostered as an aid and guide in obtaining the best results. At Mount Edgcumbe, the sugar industry has, at a cost of $£ 13,000$, established an experimental station, which is run at an annual charge of about $£ 9,000$. On the agricultural side, its main function is the search for new canes of superior sugar content and of higher resistance to disease. There are also a chemical side, dealing with manufacturing methods and processes, and an engineering section to investigate mechanical problems.

The Union Government conducts research in connexion with the fisheries, investigating life-histories and the intensity of operations and engaging in technological research on canning, smoking and other processes. Marine biological work is carried on in the specially designed research ship Africana, which took over the duties in 1931, while shore investigations in this department are conducted at the Laboratory and Aquarium at St. James, near Cape Town.

In a country making rapid advances towards industrialism, and possessing rich stores of natural wealth, much special research is necessary in order

* Industrial Development in South Africa and Facilities for the Establishment of Factories. Published by the Department of Commerce and Industries. Edited by
Government Printer, 1936.) 18. to ascertain the best methods of making use of and adapting its resources to its own needs and that of export trade. Such work is being done on the coal supplies, the phosphates, the clays and other materials offering scope for increased usefulness. The use of gas, for example, might be greatly increased and developed.

The value of standardization has been recognized, and the editor takes the opportunity of impressing on his local readers its importance in eliminating ambiguous and misleading descriptions, in preparing dimensional standards and in specifying physical and chemical properties of materials, methods of testing, and safety codes. The South African Standards Institution, which is associated with the British Standards Institution, is conducted by a main committee representative of Government departments, technical societies and trade and industrial bodies, and there are five sectional committees dealing with mechanical, electrical and civil engineering, chemical and fuel matters respectively. In any work undertaken, the initiative lies with the interests concerned, and after tentative standards have been prepared they are submitted to the associated institutions, and those chosen are circulated for comment and recommendation. It is claimed that in this way the final standards approved should meet local conditions and requirements and then the industry or trade concerned may, if it desires, adopt them in its daily policy and practice.

It is to be noted also that a comprehensive scheme of training and technical education is now in being. The adoption, in 1922, of the Apprenticeship Act, marked the beginning of a new era in industrial legislation, and since then, 15,000 lads have completed their apprenticeships in accordance with its provisions and under the supervision of the committees of employers and employees which assist in its administration. The Act is operative in twelve groups of industries, and the general practice is a five-year training of young people after completing the primary and, in some cases, part of the secondary school course. They are then indentured to individual employers and are required to enrol for part-time courses at the technical colleges, a portion of their attendance there being timed to take place during ordinary working hours. For those resident in places far removed from centres where technical colleges exist, the Government has arranged for correspondence courses under the ægis of the Witwatersrand Technical College and, where students show satisfactory diligence, employers are responsible for the class or correspondence fees. It will thus be seen that South Africa is making every endeavour to provide for the needs of her technical students in the most practical way, and it may be premised that these preparations will react most favourably upon future industrial developments. 